\title{
Improving Students' Productive Disposition through Realistic Mathematics Education with Outdoor Approach
}

\author{
Saleh Haji ${ }^{*}$, Yumiati $^{2)}$, Zamzaili ${ }^{1)}$ \\ 1) Department of Mathematics Education, Bengkulu University, Bengkulu, INDONESIA \\ ${ }^{2)}$ Department of Mathematics Education, Open University, Bengkulu, INDONESIA \\ 'Corresponding authors: salehhaji@unib.ac.id
}

\begin{abstract}
This study aimed to improve the students' productive disposition (PD) through Realistic Mathematics Education (RME) learning with an outdoor approach based on school level. Productive disposition development is intended so that students can appreciate mathematics as a science needed for their lives. The method used in this research was a quasi-experimental study. The population was 210 students of the fifth grade of Elementary School from five schools. The sample was 75 fifth grade students. The data were collected by using a questionnaire. Data were analyzed using t-test to find out the difference between the experimental and the control group. The results of this study indicate that $\mathrm{RME}$ learning with the outdoor approach more influential than the conventional learning in improving PD in high school level. Otherwise, in medium and low level school, the conventional learning was more influential than the RME learning with the outdoor approach to improve the students' PD. Therefore, it can be concluded that the school level needs to be considered in improving students' productive disposition through RME learning with an outdoor approach. Moreover, RME learning with an outdoor approach as an alternative model to improve productive disposition of students.
\end{abstract}

Keywords: Productive Disposition, Realistic Mathematics Education, Outdoor Approach.

Received: $2^{\text {nd }}$ July 2019 ,Revised: $13^{\text {th }}$ August 2019, Accepted: $13^{\text {st }}$ August 2019

\section{Introduction}

Developing attitudes and habits of elementary school students who view mathematics as useful knowledge for their lives is not an easy thing because mathematics is an abstract knowledge contained in the human mind. Mathematics is the science of the organized structure (Saleh Haji \& Yumiati, 2018). The form of the structure is abstract from mathematics in the form of symbols, operations, and formulas. In fact, the teachers do not develop productive disposition towards mathematics. They tend to teach mathematical concepts and skills rather than developing attitudes towards mathematics (productive disposition). Only a small number of mathematics teachers focus on developing the students' mathematical dispositions during the process of teaching mathematics rather than developing the students' procedural fluency and strategic competence (An et al., 2015). Increasing the productive disposition of students needs to be done, so that students are enthusiastic in learning mathematics. Haji \& Yumiati (2018) 
suggested that $73 \%$ of school students did not like mathematics, so their mathematics learning outcomes were low.

This abstract knowledge of mathematics is difficult to understand by elementary school students who are at the stage of thinking concrete operations. At this stage, the students will be more easily in responding to the concrete things. Children aged 7-12 years old are at the stage of concrete operations (Ruseffendi, 2006). At this stage, children can understand abstract logical operations with the help of concrete objects. $67 \%$ of elementary school students in Bengkulu City do not like mathematics and are less motivated in learning mathematics (Maezaro \& Haji, 2014). Learning that takes place in the classroom makes the students feel bored and have no motivation to learn (Widiasworo, 2017).

The students' positive productive disposition towards mathematics can be built through the Realistic Mathematics Education (RME) learning model with the outdoor approach. Through the Realistic Mathematics Education learning, the students carry out mathematical activities from the contextual things that can be in the form of everyday life problems towards formal mathematical activities in the form of models and concepts. Through horizontal mathematical activities, productive disposition towards mathematics is built. Realistic Mathematics Education has a positive impact on the students' productive disposition towards mathematics (Özkaya \& Yetim, 2017). Realistic Mathematics Education makes students being aware of the connections and uses of mathematics for everyday life.

The mathematical activities presented by the RME can make the students being challenged to solve a problem. The mathematical learning with an outdoor approach can improve productive disposition towards mathematics (Peng \& Sollervall, 2014). Students who did not like mathematics became happy with mathematics, after they got the RME learning.

Realistic Mathematics Education (RME) learning model with the outdoor approach can stimulate the interest of the students to take lessons to improve the knowledge, attitudes, and skills of the students (Widiasworo, 2017). Improving productive disposition can develop other mathematical abilities like problem solving skill (Noriza, Kartono, \& Sugianto, 2016).

The general statement of this problem was "Could Realistic Mathematics Education learning with the outdoor approach improve the mathematical productive disposition of the elementary school students viewed from the school levels?" Based on the problem statement, the general objective of this study was to improve the mathematical productive disposition of the students through Realistic Mathematics Education learning with the outdoor approach viewed from the school levels.

The Realistic Mathematics Education (RME) learning model with the outdoor approach is a RME learning model that is conducted outside the classroom. The learning model has five elements: 1) Syntax, 2) Social system, 3) Principle of reaction, 4) Support system, and 5) Instructional and accompaniment impacts (Joyce \& Weil, 1986).

\section{Research Methods}

The type of the research was a quasi-experimental study. Because there are several variables that cannot be controlled, such as the mental condition of students. The sampling in the experimental and control classes wasnotdone randomly, because the experimental and control classes are available at school. Researchers used conditions that are available at school.The quasi-experimental method was used when random assignments of subjects to the experitamental and control groups were sometimes not possible (Borg \& Gall, 1985). This research was conducted in five elementary schools in Bengkulu City, namely: SDN 1 (high level school); SDN 11, 65, and 67 (medium level 
schools); and SDN 72 (low level school). The time of the research was on February October 2018. The population was 210 students of the fifth grade of Elementary School. The sample was 75 students of the fifth grade of elementary school.

The instrument of this research was a productive disposition questionnaire which contained 10 items of statements consisting of 5 items of positive statements and 5 items of negative statements. Some of the items are as follows, 1) Mathematics makes my thinking work and 2) mathematics makes me thinking meticulously. The data analysis was carried out using qualitative and quantitative method. The procedures of data analysis are as follows: 1) compile hypotheses, 2) test hypotheses, 3) interpretation, and 4) conclude.

\section{Results and Discussion}

Productive Disposition (PD) is the tendency to see mathematics as logical (plausible), useful, and valuable scienceand related to the belief and persistence. PD indicators used in this research were: a. logic, b. the use of mathematics, c. attitude, d. belief, and e. persistence. To measure PD, questionnaire in the form of choicewith 5 (five) choices was used, namely strongly disagree, disagree, hesitate, agree, and strongly agree. The maximum score for each statement was 5 so that the maximum total score for PD questionnaire was 55. PD questionnaire was given before and after the learning process both in the experimental and control classes.

The activities of the students and teacher which are based on the principles and characteristics of the RME areconducted outside the classroom so that they formthe RME learning with the outdoor approach. The outdoor mathematics learning is an activity of mathematics learning conducted outside the classroom (Humble, 2007). The syntax of the RME learning model with the outdoor approach consists of: 1) Introduction, 2) Core activities, and 3) Closing. In the introduction, the teacher conditions a conducive classroom atmosphere, performs apperception, conveys learning objectives, conveys ways of learning and activities outside the classroom, forms groups of students, delivers a topic of material, and conveys contextual problems that must be solved by the students. The core section contains the following learning activities: the teacher invites the students out of the classroom, the students solve contextual problems through the activities of observing real objects of daily life; measuring, calculating, drawing, manipulating, discussing, interviewing, playing, reflecting, and discovering. The teacher guides and facilitates the activities of the students outside the classroom. In the closing section, the students present their findings in solving the contextual problems as well as the learning materials they obtain during the activities outside the classroom. The students draw conclusions about the findings of the learning materials and the results of solving contextual problems. The teacher establishes and corrects the results of solving contextual problems and the findings of the learning materials obtained by the students. The teacher gives questions about the materials obtained by the students and explains a topic of material for the next meeting. The social system creates a good relationship between students, between students and teacher, and between students and learning objects or resources. The principle of reaction is the freedom of the students to convey mathematical ideas to their friends and teacher. The support system is the availability and ease of access to various learning resources outside the classroom. The instructional and accompaniment impacts are the broader knowledge and experiences of the students. In addition, there are the intimacy among students and the closeness between mathematics and everyday life.

Productive disposition is a positive attitude and habit to see mathematics as something logical and useful for life (Kilpatrick, Swafford, \& Findell, 2001). Productive disposition is the tendency for habits to see mathematics as logic, usefulness, valuable, 
belief, and persistence (Siegfried \& Michael, 2012). The indicators of productive disposition in learning mathematics are 1) enthusiasm, 2) attention, 3) persistence, 4) confidence, 5) flexibility, 6) curiosity, and 7) cooperation (Lestari \& Yudhanegara, 2015).

Figure 1 shows the students counting the number of vehicles parked on the school yard.

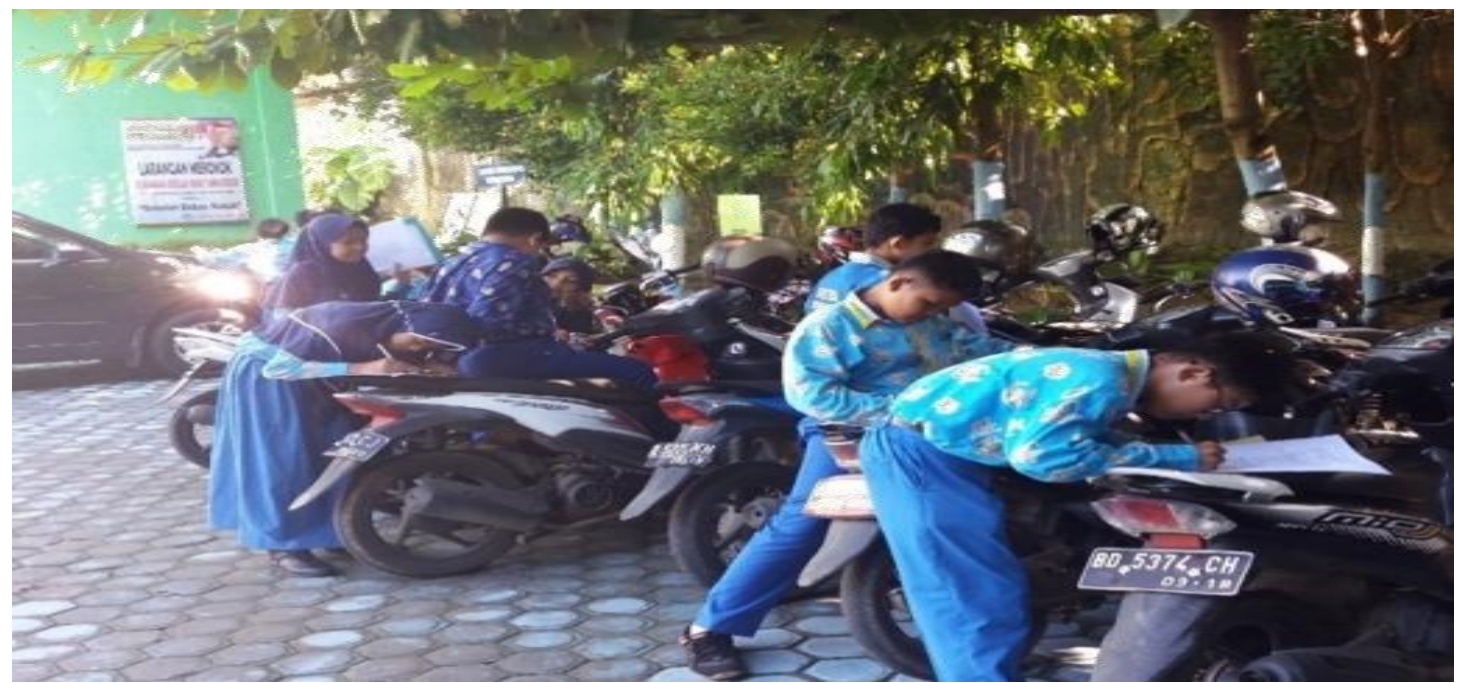

Figure 1. The Students' Activity in the RME Learning with the Outdoor Approach in Forming Productive Disposition

Table 1. Descriptive Data of the students' PD for Each School Level and Overall

\begin{tabular}{clllllll}
\hline \multirow{2}{*}{$\begin{array}{c}\text { School } \\
\text { Level }\end{array}$} & \multirow{2}{*}{ Type of Data } & \multicolumn{3}{c}{ Experiment } & \multicolumn{3}{c}{ Control } \\
\cline { 2 - 7 } High & Total & 31 & 31 & 31 & 31 & 31 & 31 \\
& Min. Score & 26 & 22 & -0.86 & 19 & 24 & -1 \\
& Max. Score & 51 & 52 & 0.67 & 52 & 55 & 1 \\
& Average & 41.09 & 42.48 & 0.08 & 42.55 & 43.03 & -0.005 \\
& Standard Dev. & 5.50 & 6.11 & 0.29 & 6.08 & 5.17 & 0.36 \\
\hline Medium & Total & 20 & 21 & 20 & 21 & 20 & 21 \\
& Min. Score & 32 & 30 & -0.67 & 32 & 31 & -0.62 \\
& Max. Score & 46 & 51 & 0.71 & 51 & 51 & 0.60 \\
& Average & 40.75 & 41.50 & 0.03 & 43.24 & 44.29 & 0.06 \\
& Standard Dev. & 3.97 & 5.42 & 0.35 & 4.47 & 5.01 & 0.34 \\
\hline \multirow{2}{*}{ Low } & Total & 22 & 23 & 22 & 23 & 22 & 23 \\
& Min. Score & 38 & 38 & -1 & 37 & 39 & -1.25 \\
& Max. Score & 51 & 52 & 0.73 & 51 & 50 & 0.69 \\
& Average & 43.50 & 43.68 & -0.04 & 45.00 & 45.35 & -0.07 \\
& Standard Dev. & 3.60 & 4.30 & 0.43 & 4.03 & 3.17 & 0.40 \\
\hline \multirow{2}{*}{ Overall } & Total & 75 & 75 & 75 & 75 & 75 & 75 \\
& Min. Score & 26 & 22 & -1 & 19 & 24 & -1.25 \\
& Max. Score & 51 & 52 & 0.73 & 52 & 55 & 1 \\
& Average & 41.71 & 42.57 & 0.03 & 43.49 & 44.09 & -0.01 \\
& Standard Dev. & 4.71 & 5.44 & 0.35 & 5.13 & 4.65 & 0.37 \\
\hline
\end{tabular}

The RME learning with the outdoor approach discussed aboutthe material of the Data Presentation for the students of the fifth grade of Elementary School as an experimental class. On the other hand, the conventional learning was conducted in the control class. The Productive Disposition (PD) results of the students in the 
experimental and control classes based on the school levels are presented in Table 1 below.

The improvement of the students' PD who were taught through the realistic mathematics education learning with the outdoor approach was higher than the students who were taught through the conventional learning. The improvement of the students' PD in the experimental class was 0.03, while the students' PD in the control class was 0.01. This means that the students' PD in the experimental class was better than the students' PD in the control class. The students in the experimental class were more enthusiastic in learning mathematics. They were eager to solve a contextual problem by discussing it with their friends. They had high curiosity about the meanings of the contextual problems and the solutions. The result shows that the realistic mathematics education learning with the outdoor approach influenced the improvement of the students' PD. This is in line with the results of the previous researches. The realistic mathematics education had an effect on the students' attitudes in learning mathematics (Syamaun \& Zakaria, 2017). The results of other researches show that the realistic mathematics education learning could develop the characters of the students who were creative, independent, democratic, and curious (Saleh Haji, 2012). They also show that the characters of the elementary school students could be developed through the outside learning (Haji \& Zamzaili, 2018). In addition, they show that the realistic mathematics approach with the inquiry method influenced the improvement of the positive characters of the students towards mathematics (Nursanti, Rochsantiningsih, Joyoatmojo, \& Budiyono, 2016).

All indicators of PD were found in the students in the experimental class. On the other hand, the students in the control class, some indicators of PD were less visible, namely: 1) lack of persistence in dealing with problems, 2) lack of curiosity, c) lack of sharing opinions with others.

Based on the school levels, the improvement of the influence of the realistic mathematics education learning with the outdoor approach for the students of high level school was greater than the students of medium level schools. The improvement of the students' PD of high level school was 0.08, while the improvement of the students' PD of medium level schools was 0.03. Likewise, the improvement of the influence of the realistic mathematics education learning with the outdoor approach for the students of medium level schools was greater than the students of low level school. The improvement of the students' PD of medium level schools was 0.03 , while the improvement of the students' PD of low level school was -0.04 . This shows that the school levels influenced the improvement of the students' PD. The PD of the students of high level school wasgreater than the students of medium and low level schools in the terms of 1) curiosity, 2) persistence and diligence, and 3) enthusiasm in the learning process.

Figure 2 shows the averages of the pre and post of the students' PD for each school level and overall. 


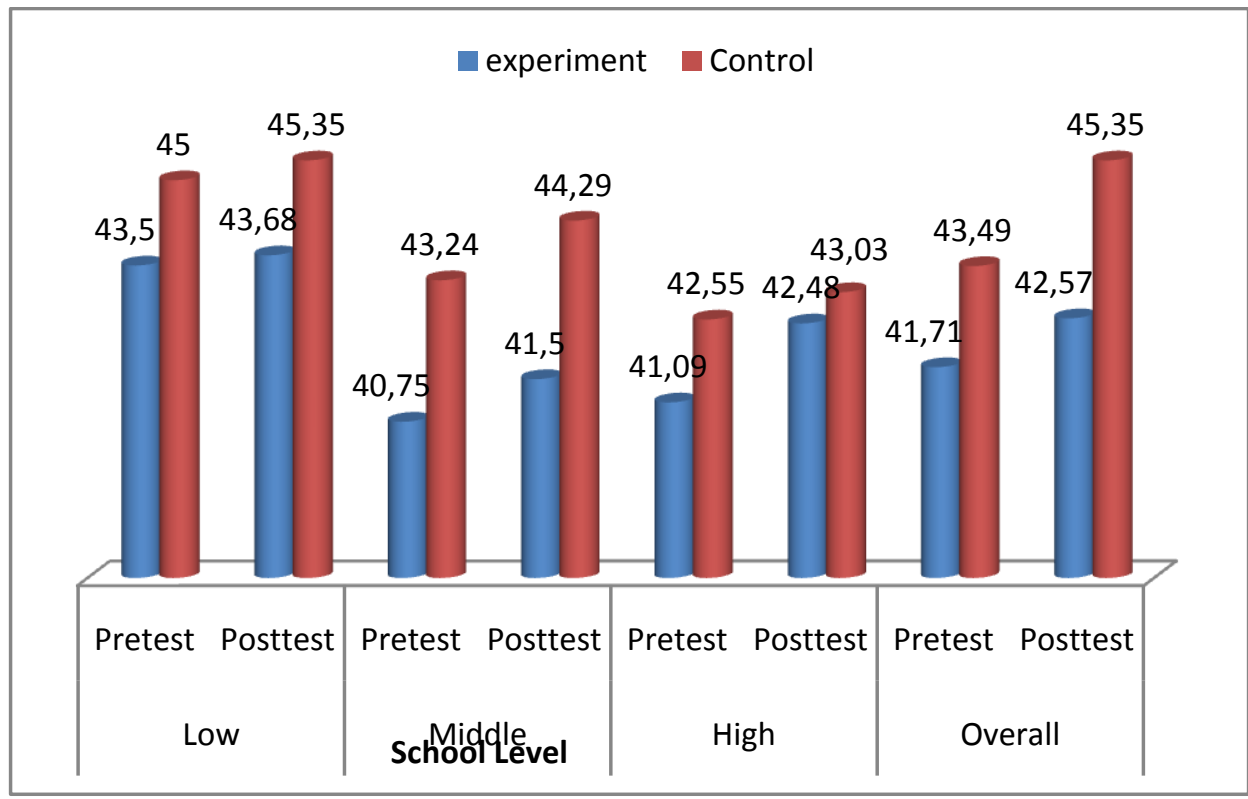

Figure 2. Data of Average Scores of the students' PD for Each School Level and

\section{Overall}

Based on Figure 2, it can be seen that the post scores of the students' PD were higher than the pre scores of the students for all classes (experimental and control), each school level (high, medium, low), and the whole class. This shows that both the RME learning with the outdoor approach and the conventional learning had an effect on improving the the students' PD. The interesting thing found in Figure 2 is that the pre and post scores of the students' PD in the experimental class were lower than the students in the control class, both for each school level and overall. Figure 3 shows the improvement of the students' PD for each school level and overall.

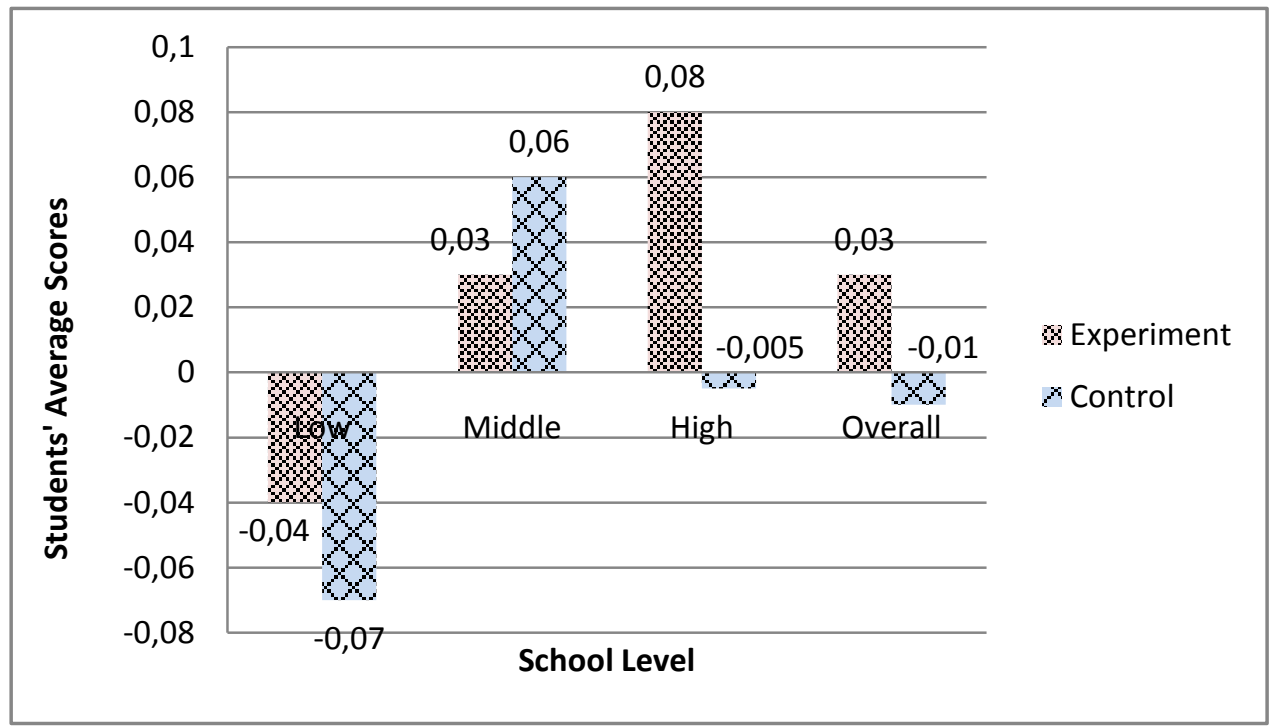

Figure 3. Data of N-gain of the students' PD for Each School Level and Overall

From Figure 3, it can be seen that overall the improvement (N-gain) of PD of the students in the experimental class was higher than the students in the control class, except for the mediumlevel schools, the $\mathrm{N}$-gain of the students in the experimental class was lower than the students in the control class. All the N-gain of the students were in the low category. The interesting thing found is that, the post scores of the students' PD 
were higher than the pre scores of the students' PD in the control class for each school level and overall. However, if it was viewed on the $\mathrm{N}$-gain, the $\mathrm{N}$-gain of the students in the control class was negative.

The normality of the data of PD was analyzed using the Kolmogorov-Smirnov test. The test results showed that overall the data of PD in the experimental group were abnormal, while the data in the control group were normal. The results of the analysis are presented in Table 2.

Table 2. Test results for the Normality of the Data of the Students' PD

\begin{tabular}{|c|c|c|c|c|c|}
\hline \multirow{2}{*}{$\begin{array}{c}\text { School } \\
\text { Level }\end{array}$} & \multirow{2}{*}{ Type of Data } & \multicolumn{3}{|c|}{ Kolmogorov-Smitnov } & \multirow{2}{*}{ Conclusion } \\
\hline & & Statistic & $\mathrm{Df}$ & Sig. (2-way) & \\
\hline \multirow[t]{6}{*}{ High } & Pre_PD_Exp. & 0.081 & 33 & 0.200 & Normal \\
\hline & Pre_PD_Control & 0.183 & 31 & 0.010 & Abnormal \\
\hline & Post_PD_Exp. & 0.160 & 33 & 0.031 & Abnormal \\
\hline & Post_PD_Control & 0.158 & 31 & 0.046 & Abnormal \\
\hline & N-gain_PD_Exp. & 0.144 & 33 & 0.081 & Normal \\
\hline & N-gain_PD_Control & 0.114 & 31 & 0.200 & Normal \\
\hline \multirow{6}{*}{ Medium } & Pre_PD_Exp. & 0.193 & 20 & 0.048 & Abnormal \\
\hline & Pre_PD_Control & 0.133 & 21 & 0.200 & Normal \\
\hline & Post_PD_Exp. & 0.141 & 20 & 0.200 & Normal \\
\hline & Post_PD_Control & 0.181 & 21 & 0.070 & Normal \\
\hline & N-gain_PD_Exp. & 0.086 & 20 & 0.200 & Normal \\
\hline & N-gain_PD_Control & 0.105 & 21 & 0.200 & Normal \\
\hline \multirow{6}{*}{ Low } & Pre_PD_Exp. & 0.172 & 22 & 0.090 & Normal \\
\hline & Pre_PD_Control & 0.120 & 23 & 0.200 & Normal \\
\hline & Post_PD_Exp. & 0.198 & 22 & 0.025 & Abormal \\
\hline & Post_PD_Control & 0.136 & 23 & 0.200 & Normal \\
\hline & N-gain_PD_Exp. & 0.174 & 22 & 0.080 & Normal \\
\hline & N-gain_PD_Control & 0.135 & 23 & 0.200 & Normal \\
\hline \multirow[t]{6}{*}{ Overall } & Pre_PD_Exp. & 0.100 & 75 & 0.060 & Normal \\
\hline & Pre_PD_Control & 0.088 & 75 & 0.200 & Normal \\
\hline & Post_PD_Exp. & 0.132 & 75 & 0.003 & Abnormal \\
\hline & Post_PD_Control & 0.127 & 75 & 0.004 & Abnormal \\
\hline & N-gain_PD_Exp. & 0.128 & 75 & 0.004 & Abnormal \\
\hline & N-gain_PD_Control & 0.081 & 75 & 0.200 & Normal \\
\hline
\end{tabular}

Table 3. Homogeneity Test Results of the Data of the Students' PD

\begin{tabular}{|c|c|c|c|c|c|}
\hline School Level & Type of Data & $\mathrm{N}$ & $\mathrm{F}$ & Sig. (2-way) & Conclusion \\
\hline \multirow[t]{2}{*}{ High } & N-gain_PD_Exp. & 33 & \multirow{2}{*}{0.839} & \multirow{2}{*}{0.363} & \multirow{2}{*}{ Homogeneous } \\
\hline & N-gain_PD_Control & 31 & & & \\
\hline \multirow{2}{*}{ Medium } & Post_PD_Exp. & 20 & \multirow{2}{*}{0.135} & \multirow{2}{*}{0.716} & \multirow{2}{*}{ Homogeneous } \\
\hline & Post_PD_Control & 21 & & & \\
\hline \multirow{2}{*}{ Medium } & N-gain_PD_Exp. & 20 & \multirow{2}{*}{0.032} & \multirow{2}{*}{0.860} & \multirow{2}{*}{ Homogeneous } \\
\hline & N-gain_PD_Control & 21 & & & \\
\hline \multirow{2}{*}{ Low } & Pre_PD_Exp. & 22 & \multirow{2}{*}{0.327} & \multirow{2}{*}{0.571} & \multirow{2}{*}{ Homogeneous } \\
\hline & Pre_PD_Control & 23 & & & \\
\hline \multirow{2}{*}{ Low } & N-gain_PD_Exp. & 22 & \multirow{2}{*}{0.207} & \multirow{2}{*}{0.652} & \multirow{2}{*}{ Homogeneous } \\
\hline & N-gain_PD_Control & 23 & & & \\
\hline \multirow{2}{*}{ Overall } & Pre_PD_Exp. & 75 & \multirow{2}{*}{0.013} & \multirow[t]{2}{*}{0.909} & \multirow{2}{*}{ Homogeneou } \\
\hline & Pre_PD_Control & 75 & & & \\
\hline
\end{tabular}

Based on Table 2, a pair of data (data of the experimental and control classes) which were normally distributed were the data of N-gain of PD of the high level school students, post and N-gain of PD of the medium level schools students, pre and $\mathrm{N}$-gain 
of PD of the low level school students, and pre of PD of the students on the whole. Thus, the six groups of the data needed to be tested for the homogeneity. The homogeneity analysis results of the data in Table 3 show that the six pairs of the data groups were homogeneous. Furthermore, hypothesis testing was done using the t-test and Mann Whitney test. The data of the students' PD for each school level and overall are presented in Table 4.

Table 4. Discrimination Test Results ofthe Data of the Students' PD

\begin{tabular}{clllll}
\hline $\begin{array}{c}\text { SchoolL } \\
\text { evel }\end{array}$ & \multicolumn{1}{c}{ Type of Data } & N & Average & Statistics & Conclusion \\
\hline High & Pre_PD_Exp. & 33 & 41.09 & Mann & Accepted \\
& Pre_PD_Control & 31 & 42.55 & Whitney & \\
& Post_PD_Exp. & 33 & 42.48 & Mann & Accepted \\
& Post_PD_Control & 31 & 43.03 & Whitney & \\
& N-gain_PD_Exp. & 33 & 0.08 & t-test & Accepted \\
& N-gain_PD_Control & 31 & -0.005 & & \\
\hline Medium & Pre_PD_Exp. & 20 & 40.75 & Mann & Rejected \\
& Pre_PD_Control & 21 & 43.24 & Whitney & \\
& Post_PD_Exp. & 20 & 41.50 & t-test & Rejected \\
& Post_PD_Control & 21 & 44.29 & & \\
& N-gain_PD_Exp. & 20 & 0.03 & t-test & Accepted \\
& N-gain_PD_Control & 21 & 0.06 & & \\
\hline Low & Pre_PD_Exp. & 22 & 43.50 & t-test & Accepted \\
& Pre_PD_Control & 23 & 45.00 & & \\
& Post_PD_Exp. & 22 & 43.68 & Mann & Rejected \\
& Post_PD_Control & 23 & 45.35 & Whitney & \\
& N-gain_PD_Exp. & 22 & -0.04 & t-test & Accepted \\
& N-gain_PD_Control & 23 & -0.07 & & \\
\hline Overall & Pre_PD_Exp. & 75 & 41.71 & t-test & Rejected \\
& Pre_PD_Control & 75 & 43.49 & & \\
& Post_PD_Exp. & 75 & 42.57 & Mann & Rejected \\
& Post_PD_Control & 75 & 44.09 & Whitney & \\
& N-gain_PD_Exp. & 75 & 0.03 & Mann & Accepted \\
& N-gain_PD_Control & 75 & -0.01 & Whitney & \\
\hline & & & &
\end{tabular}

The results of the t-test show that there were differences in the productive disposition of the students taught through the Realistic Mathematics Education learning with the outdoor approach when it was compared to the conventional approach at all levels of the school. This means that the learning process in the experimental group influenced the formation of the productive disposition of the students.

The experimental group students were eager to count the number of vehicles parked on the school yard. The data obtained by the students presented in the form of pictures. The students paid much attention and classified various types of vehicles that were parked. Even though the vehicles were not neatly arranged, the students were very persistent in observing the vehicles. They had confidence in their ability to solve various data contained in their school environment. They had flexibility in carrying out their duties to look for and present the data on the types of vehicles parked in their school environment. The students also had high curiosity about various things related to the data. They respected each other and worked together in carrying out their duties. The form of cooperation carried out by the students in communicating the mathematical ideas was found outside the classroom. The mathematical communication skills of the high level school students were better than the medium and low level schools students (Yumiati \& Haji, 2018a). These things made the productive disposition of the 
experimental group students better than the control group students. The ability of the students in the term of the cooperation that contained the elements of communication and reasoning could be improved through the Realistic Mathematics Education learning with the outdoor approach. This is in line with the research results showing that the communication and reasoning abilities of the junior high school students could be improved through the Realistic Mathematics Education learning (S. Haji \& Abdullah, 2016).

Furthermore, by paying attention to the scores of N-gain, overall there was an improvement of the productive disposition of the students by 0.03 . The improvement of the productive disposition of the students from all school levels was due to the Realistic Mathematics Education learning with the outdoor approach. The learning process had succeeded in presenting the learning atmosphere that fostered enthusiasm, attention, persistence, confidence, flexibility, curiosity, and tolerance in learning mathematics.

The improvement of the productive disposition of the students in high level school was greater than in medium and low level schools. On the other hand, the improvement of the productive disposition of the students in medium level schools was higher than in low level schools. The order of the differences of the productive disposition of the students in low, medium and high level schools was in accordance with the order of the differences in expressing generality abilities (Yumiati \& Haji, 2018b). The improvement of the productive disposition of the students in high level school was 0.08 , medium level schools was 0.03, and low level school was -0.04 . These findings are in accordance with Fitrianna, Dinia, Mayasari, \& Nurhafifah (2018) which state thatstudents with high mathematical disposition have been able to present data/information from a representation into diagrams, graphs or tables and solve a problem using written words or texts. This was because the students in high level school had better sensitivity and adaptation than the students in medium and low level schools. Likewise, sensitivity and adaptation of the students in medium level schools were better than the students in low level schools.

The results of this study have an impact on students, teachers, and schools. The impact to the students is as follows. Students become motivated in learning mathematics. They learn mathematics with enthusiasm accompanied by feelings of pleasure. The impact to the teacher is to make the teacher happy in teaching mathematics. While the impact on schools is to make the academic atmosphere in schools being more conducive. The contribution of the results of this study to the development of the science of mathematical education is to enrich the insights into science from mathematics education from aspects of the learning model and its relation to aspects of productive disposition.

\section{Conclusion}

The Realistic Mathematics Education learning model with the outdoor approach could improve the ability of the mathematical productive disposition of the elementary school students by 0.03 . In theory, the implication of this result is to strengthen the results of previous studies which state that realistic mathematics learning influences students' attitudes towards mathematics. Practically, the results of this study serve as guidelines for teachers and students in implementing mathematics learning. In high level school, the pre, post, and N-gain of the students' PD in both classes did not differ significantly. It can be said that although the two classes of the improvement of the students' PD did not differ significantly, the RME learning with the outdoor approach was slightly more influential than the conventional learning in improving the students' PD in high level school. In medium level schools, the pre and post of the students in the experimental class were significantly lower than the students in control class. However, the N-gain of the students in both classes did not differ significantly. It can be said that 
the conventional learning was slightly more influential than the RME learning with the outdoor approach to the achievement and improvement of the abilities of the students' PD. This means that the conventional learning was more suitable to be implemented in medium level schools. In low level school, the pre and N-gain of the students' PD in both classes did not differ significantly. Meanwhile, the achievement (post) of the students' PD in the control class was significantly higher than in the experimental class. The pre and N-gain of the students in both classes did not differ significantly. Meanwhile, the post of the students in the experimental class was significantly better than the students in the control class.

\section{Acknowledgement}

An earlier version of this paper entitled "Improving Productive Disposition of the Students Through Realistic Mathematics Education Learning with Outdoor Approach in Elementary School Based on School Level" was presented at the Konferensi Nasional Penelitian Matematika dan Pembelajarannya (KNPMP) IV 2019 held by Department of Mathematics Education, Universitas Muhammadiyah Surakarta, Indonesia, 27 ${ }^{\text {th }}$ March 2019.

\section{Bibliography}

An, S. A., Zhang, M., Flores, M., Chapman, J. R., Tillman, D. A., \& Serna, L. (2015). Music Activities as an Impetus for Hispanic Elementary Students' Mathematical Disposition. Journal of Mathematics Education, 8(2), 39-55. Retrieved from http://educationforatoz.com/images/2015_Song_An.pdf

Borg, W. R., \& Gall, M. D. (1985). Educational Research: An Introduction. USA: Longman, Inc.

Fitrianna, A. Y., Dinia, S., Mayasari, \& Nurhafifah, A. Y. (2018). Mathematical Representation Ability of Senior High School Students: An Evaluation from Students' Mathematical Disposition Mathematical Representation Ability of Senior High School Students: An Evaluation from Students' Mathematical Disposition. Journal of Research and Advances in Mathematics Education, 3(1), 46-56.

Haji, S., \& Abdullah, I. (2016). Mathematical communication and reasoning abilities (implementation of Realistic Mathematics learning at SMP Bengkulu City). Second International Seminar. Bengkulu: Universitas Bengkulu.

Haji, S, \& Zamzaili. (2018a). Building students' character through outdoor mathematics learning. Proceeding International Seminar of Education and Counseling 2018.

Haji, Saleh. (2012). Developing students' character through realistic mathematics learning. Proceeding the 3rd International Seminar 2012. Bandung: Universitas Pendidikan Indonesia.

Haji, Saleh, \& Yumiati. (2018b). Nilai-nilai matematika pada batik Besurek Bengkulu. Jurnal Pendidikan Matematika Reflesia, 3(1), 1-9.

Humble, S. (2007). Maths on the Quayside. Retrieved from Newcastle website: www.ncetm.org.uk

Joyce, B., \& Weil, M. (1986). Models of Teaching. New York: Harper \& Row.

Kilpatrick, J., Swafford, J., \& Findell, B. (2001). Adding It Up: Helping Children Learn Mathematics. Washington, DC: National Academy Press.

Lestari, K. E., \& Yudhanegara. (2015). Penelitian Pendidikan Matematika. Bandung: PT Refika Aditama.

Maezaro, S., \& Haji, S. (2014). Model pembelajaran outdoor mathematics untuk meningkatkan kemampuan koneksi dan komunikasi siswa sekolah dasar. Bengkulu.

Noriza, Kartono, \& Sugianto. (2016). Problem solving and mathematical disposition based on level thinking by PBL Van Hiele Approach. Journal of Mathematics Education, 
10(2).

Nursanti, Y. B., Rochsantiningsih, D., Joyoatmojo, S., \& Budiyono. (2016). Mathematics education in Indonesia through inquiry based Realistic Mathematics Education approach to improve character. International Journal of Education and Research, 4(9).

Özkaya, A., \& Yetim, K. . (2017). The effects of Realistic Mathematics Education on students' achievements and attitudes in fifth grades mathematics courses. International Online Journal of Education and Teaching (IOJET), 4(2), 185-197.

Peng, A., \& Sollervall, H. (2014). Primary school students' spatial orientation strategies in an outdoor learning supported by mobile technologies. International Journal of Education in Mathematics, Science, and Technology., 2(4), 246-245.

Ruseffendi, H. E. . (2006). Pengantar kepada Membantu Guru Mengembangkan Kompetensinya dalam Pengajaran Matematika untuk Meningkatkan CBSA. Bandung: Tarsito.

Siegfried, \& Michael, J. . (2012). The Hidden Strand of Mathematical Proficiency: Defining and Assessing for Productive Disposition in Elementary School Teachers' Mathematical Content Knowledge. University of California.

Syamaun, \& Zakaria. (2017). The effect of realistic mathematics education approach on students' achievement and attitudes towards mathematics. Mathematics Education Trends and Research, (1), 32-40.

Widiasworo, E. (2017). Strategi \& Metode Mengajar Siswa di Luar Kelas. Yogyakarta: ArRuzz Media.

Yumiati, \& Haji, S. (2018a). Ability of students' mathematical connection based on school level in junior high school. Journal of Physics: Conference Series, 1116(2), 0-10. https://doi.org/10.1088/1742-6596/1116/2/022047

Yumiati, Y., \& Haji, S. (2018b). The Students Ability of Expressing Generality in Numbers at Junior High School Based on School Level. 262(Ictte), 225-229. https://doi.org/10.2991/ictte-18.2018.39 